\title{
PROBLEMS OF LEARNING SPEAKING SKILLS ENCOUNTERED BY ENGLISH MAJOR STUDENTS AT BA RIA-VUNG TAU UNIVERSITY, VIETNAM
}

\author{
Huynh Thi Anh Tram \\ Faculty of Foreign Languages \\ and Social Sciences, \\ Ba Ria-Vung Tau University, \\ Vietnam
}

\begin{abstract}
:
Speaking skills is one of the four major language skills that most language learners desire to master in order to communicate effectively in different contexts. It is important to determine main factors hindering learners to speak English fluently. In order to achieve the aim of discovering and analyzing the problems in learning speaking skills faced by English major students at Ba Ria-Vung Tau University (BVU), 65 students participated in this study by completing the questionnaire made by the researcher. The result reveals that the dominant problems these students often encounter are associated with linguistic problems and non-linguistic problems. Although students have striven to deal with their learning speaking problems, but their attempts seem to be unsuccessful. Therefore, some recommendations in the light of findings are also presented in this paper.
\end{abstract}

Keywords: speaking skills, problems, linguistic problems, non-linguistic problems

\section{Introduction}

English is considered as an international language and widely used in many fields including business, science, politics and media all over the world. Nowadays, in the globalization era, due to the demand of international integration, English increasingly becomes the most desirable language to be mastered. Many schools and universities around the world have put English as a compulsory subject in their national academic curriculums. According to Nunan (1991), among English language skills, speaking is the most important aspect of learning a foreign language, and success is measured in terms of the ability to carry out a conversation in that language. Speaking, hence, seems to be the most important skills that should be focused on more in the process of teaching and learning English. It is obvious that learners expect to master four major skills: reading,

i Correspondence: email tramhta@bvu.edu.vn, anhtram2110@gmail.com 
listening, writing and speaking equally, but in fact, speaking skills of many EFL learners is not as good as other skills. This situation has been occurring at Ba Ria-Vung Tau University (BVU) in Vietnam for years. A common problem encountered by a large number of students is that they are quite proficient in reading and listening skills; yet, they are unable to speak English fluently although they have learnt English since primary education. In other words, the majority of students find it difficult to express their opinions or orally communicate in English with other people. Particularly, when students are required to give a talk or make an argument, most of them are speechless or spend much time thinking of what they are going to say. Bedsides, when being asked to present a certain topic, students tend to read material they have prepared rather than naturally present key messages to the audience.

This study, therefore, is conducted with the aim of discovering, analyzing English major students' problems in speaking English as well as suggesting feasible solutions to address the situation.

\section{Theoretical Background}

\subsection{Definition of Speaking}

It is obvious that speaking is the key means of human communication. It enables people to express their feelings, opinions and to communicate with other people in the world. There are many experts defining "speaking" as follows:

Speaking is viewed to be at the heart of second language learning among the four language skills by Egan (1990). According to Brown, speaking is "a constructing meaning interactive process that is comprised producing and receiving information". Furthermore, Harris (1974) defines speaking as the encoding process whereby we communicate our ideas, thought, and feeling orally. It means that we produce spoken message to someone. The spoken message includes ideas, thought and feeling that we want to share, influence, or interact to other people. Similarly, Byrne (1984) states "speaking is a two-way process between speaker and listener and involves productive and receptive skills of understanding". It means that the speaker has to convey message in appropriate language so that the listener can decode that message. Meanwhile, Lado (1964) describes speaking as the ability to express oneself in life situation, or the ability to report acts or situations in precise words, or the ability to converse, or to express a sequence of ideas fluently. This idea means that speaking emphasizes more to the ability of an individual to convey something whether it is in the form of expression, report, etc. with the language he has. Additionally, Chaney \& Burk (1998) defines speaking as "a process of building and sharing meaning through the use of verbal and non-verbal symbol, in a variety of contexts".

From the definition above, it can be inferred that speaking is a complex interactive process between the speakers and listeners in order to produce, decode and receive messages through the use of verbal and non-verbal symbols. In other words, speaking is a tool enabling speakers to transfer their ideas that are arranged and developed to listeners clearly, effectively and correctly. 


\subsection{Problems of Learning English Speaking Skills}

There are a number of studies examining the factors impeding EFL students' speaking skills.

Lazarton (2001) states that spoken English is difficult since it is almost accomplished through interaction with at least one interlocutor. Moreover, speaking is believed to be a demanding skill for EFL learners as they need to have not only grammar and lexical knowledge, but also knowledge of socially appropriate language by Shumin (1997). He also adds that age, aural medium, sociocultural and affective factors can affect adult EFL learners' speaking skills. Similarly, Brown (2001) claims that "colloquial language, reduced forms, performance variables, redundancy clusters, rate of delivery, stress, rhythm and intonation are among the characteristics of speaking that contribute to the difficulty of this skill." Meanwhile, according to Penny (1996), four factors that make speaking difficult for second or foreign language students are: (1) inhibition: learners are often worried about making mistakes or fearful of criticism; (2) nothing to say: even if students are not inhibited, they cannot think of anything to say or have no motive to express themselves; (3) mother-tongue use: in speaking classes, there are a number of the learners sharing the same mother tongue, so they tend to use it; because it is easier to speak to other people in a foreign language, and they feel less 'exposed' if they are speaking their mother tongue; (4) low participation: this problem is compounded by the tendency of some learners to dominate, while others speak very little or not at all.

From the explanations above, it can be concluded that there are two main kinds of difficulties learners often encountered in speaking English namely linguistic and nonlinguistic matters.

\subsection{Aspect of Speaking}

According to Harris (1974), speaking skills covers following aspects:

1) Pronunciation refers to the ability to produce easily comprehensible articulation. In other definition, pronunciation is the intonation pattern.

2) Vocabulary is the words used in a language. Nobody can communicate effectively without having sufficient vocabulary. Therefore, vocabulary means the appropriate diction that is used in communication.

3) Grammar is a rule system of units and patterns of language; or simply, it is a structured form to create meaningful sentences.

4) Fluency is the parameter of the speaking level of someone. It can be also defined as the ability to speak fluently and accurately. Without a good pronunciation, listeners cannot understand what speakers say and this will make the communication process more difficult.

5) Comprehension denotes the ability of understanding the speakers' intention and general meaning. If a person can answer or express well and correctly, it shows that he/she comprehends or understands well.

Consequently, learners need to meet those requirements above to become a proficient English speaker. 


\subsection{Strategies to Develop Learner' English Speaking Skills}

According to Brown (2001), oral communication can be maintained by three components: fluency, accuracy and pronunciation.

1) Fluency: the ability to speak spontaneously and eloquently with no pausing and with absence of disturbing hesitation markers. It also refers to "some aspects like responding coherently within the turns of the conversation, using linking words and phrases, keeping in mind a comprehensible pronunciation and adequate intonation without too much hesitation" (Richards, 2006).

2) Accuracy: the mastery of phonology elements, grammar and discourse. It also refers to the linguistic competence that deals with the correction of the utterances to get a correct communication.

3) Pronunciation: "the production and perception of the significant sounds of a particular language in order to achieve meaning in context of language use. This comprises the production and perception of segmental sounds of stressed and unstressed syllables and of the speech melody or intonation" (Carter \& Nunan, 2004).

Similarly, Lindsay \& Knight (2006) claim that learners need to produce connected speech, have interaction ability, speak in different contexts, develop a balance between accuracy and fluency, and talk about unfamiliar issues based on their knowledge.

To sum up, fluency, accuracy, pronunciation, socio-cultural knowledge are important and complementary components in the development of students' speaking skill.

\section{Research Methods}

The main research method employed in this study is descriptive analytic method to examine the English major students' problem of learning speaking. A questionnaire of 25-item speaking skills is used as a tool of data collection.

The research has been carried out as follows:

1) Doing the questionnaire: 65 BVU's English major students are asked to answer 25 questions prepared by the researcher;

2) Analyzing the results of questionnaires to discover the most frequent students' difficulties in learning English speaking skills;

3) Synthesizing the findings and drawing out conclusion.

\section{Findings and Discussions}

Through analyzing the result of the questionnaire, it is found that there are a great number of problems BVU's English major students often encounter in developing speaking skills. They are divided into two main kinds namely linguistic problems and non-linguistic ones with their most frequent items presented as follows: 
Table 1: Linguistic problems in learning speaking skills of BVU's English major students

\begin{tabular}{|l|c|c|}
\hline Linguistic problems & Frequency & Percentage \\
\hline Lack vocabulary & 59 & 90.7 \\
\hline Do not know how to use appropriate words in different contexts & 52 & 80.0 \\
\hline $\begin{array}{l}\text { Find it hard to memorize vocabulary, especially words } \\
\text { having more than one meaning. }\end{array}$ & 31 & 47.7 \\
\hline Lack grammar knowledge & 44 & 67.7 \\
\hline Have difficulty making completed sentences to express ideas & 45 & 70.7 \\
\hline Have poor pronunciation & 53 & 81.5 \\
\hline Think in Vietnamese - the mother tongue first when presenting opinion & 60 & 92.3 \\
\hline
\end{tabular}

As can be seen from the table above, almost students tend to think in their mother tongue first when they have to present their opinions, this prevents them from speaking English fluently and naturally. In addition, a large number of students are not good at speaking English since they do not have sufficient vocabulary resources (90.7\%); have poor pronunciation $(81.5 \%)$; and do not know how to use appropriate words in different contexts $(80 \%)$. Furthermore, about $70 \%$ of students doing the questionnaire believe that they lack grammar knowledge as well as have difficulties making sentences to express their opinion, which influences the accuracy and fluency when speaking English. Finally, remembering vocabulary, especially words having more than one meaning is also a problem hindering speaking skills development of nearly 50\% interviewees.

Table 2: Non-linguistic problems in learning speaking skills of BVU's English major students

\begin{tabular}{|c|c|c|c|}
\hline \multicolumn{2}{|c|}{ Non-linguistic problems } & Frequency & Percentage \\
\hline \multirow{6}{*}{ 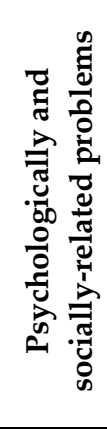 } & Be afraid of making mistakes & 59 & 90.7 \\
\hline & Be shy, not confident to speak in front of the crowd & 57 & 87.7 \\
\hline & $\begin{array}{l}\text { Be anxious to communicate in English, especially } \\
\text { foreign teacher. }\end{array}$ & 52 & 80.0 \\
\hline & Have no idea to say due to the lack of socio-cultural knowledge & 45 & 70.7 \\
\hline & $\begin{array}{l}\text { Be demotivated by better performance of other } \\
\text { students in class }\end{array}$ & 31 & 47.7 \\
\hline & $\begin{array}{l}\text { Have difficulty finding chances to practice speaking } \\
\text { skills outside the classroom }\end{array}$ & 34 & 52.3 \\
\hline \multirow{5}{*}{ 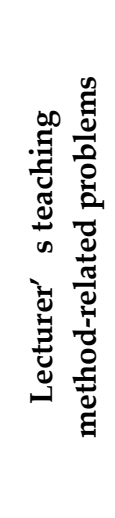 } & $\begin{array}{l}\text { Do not give interesting topic } \\
\text { for discussion }\end{array}$ & 50 & 76.9 \\
\hline & $\begin{array}{l}\text { Use traditional teaching method; do not } \\
\text { organize interesting class activities }\end{array}$ & 53 & 81.5 \\
\hline & $\begin{array}{l}\text { Pay less attention to provide idiomatic } \\
\text { expressions or collocations to present ideas. }\end{array}$ & 44 & 70.7 \\
\hline & $\begin{array}{l}\text { Not instruct students when they are unable } \\
\text { to find the appropriate words, structures } \\
\text { during their speaking. }\end{array}$ & 42 & 64.6 \\
\hline & $\begin{array}{l}\text { Have harsh error correction or } \\
\text { feedback }\end{array}$ & 26 & 40.0 \\
\hline
\end{tabular}

The figures in the above table reveal that the BVU's English major students encounter a variety of non-linguistic problems in learning speaking skills. In terms of psychologically 
and socially-related problems, the students' speaking ability is mainly affected by the fear of making mistakes $(90.7 \%)$, shyness and low self-confidence to speak in front of the crowd (87.7\%) and the feeling of anxiety about speaking English, especially with foreign teachers (80\%). Moreover, $52.3 \%$ and $47.7 \%$ students conducting the questionnaire claim that they have difficulty finding chances to practice speaking skills outside the classroom and they feel demotivated by better performance of other students in class.

Additionally, as indicated in Table 2, the students' speaking problems are associated with the lecturer's teaching methodology. Most of the students reckon that their teachers often use traditional teaching method, do not organize various class activities (81.5\%) and do not give interesting topics for discussion (76.9\%), which inhibits student-student interaction as well as their interest in speaking class. Besides, lecturers ignore to provide idiomatic expressions or collocations to present ideas $(70.7 \%)$ and they do not instruct students when they are unable to find the appropriate words, structures during their speaking (64.6\%). It is also noted that $40 \%$ students claim that lecturers' harsh error correction or feedback negatively affects their desire to learn Englishspeaking skills.

\section{Recommendations for Teaching and Learning English Speaking Skills}

\subsection{Dealing with Linguistic Problems}

Thornbury (2005) suggests that learners need to have sufficient knowledge of culture, genre, speech acts, register, discourse, grammar, vocabulary and phonology in order to manage oral communication in second language in different real-life situations. It means that learners not only need to equip themselves with mechanics of language elements (pronunciation, grammar, vocabulary) which emphasize on use of right words in the right order with the correct pronunciation, but also the functions of language that deals with speaking performance in the form of transaction and interaction and the knowledge of how native speakers use the language in the context of structured interpersonal exchange.

Concerning the problems related to vocabulary, pronunciation, English linguistic thinking, it is proposed that the lecturers use specific class time for teaching and learning the first two elements. For instance, students are guided to learn vocabulary in context, play down the role of bilingual dictionary and encouraged to determine the meaning of words. Besides, there are some ways that can be done by EFL learners including consulting the dictionary if they find unknown words to search their meanings easily as well as know how to pronounce words correctly, reading more authentic English materials or watching movies, listening to music in English, etc. in order to understand the vocabulary use of native people. Furthermore, learners need to try to remember a number of vocabulary items and use them in sentences every day so that the words are not easily forgotten. As a result, learners are able make meaningful, natural speech acts or completed sentences to express ideas in English without thinking in the mother tongue as they used to. Similarly, with respect to the lack of grammar, lecturers need to devote 
their time preparing good lesson plans containing clear explanation and useful tasks for grammatical points. More importantly, students need to attentively learn and more grammatical exercises.

\subsection{Dealing with Non-linguistic Problems}

It is undeniable that the fear of making mistake is one of the main factors leading to students' reluctance to speak English in the classroom. It is linked to the fear of being laughed at by other students or being criticized by the teacher, which makes students stop participating in the speaking activity. Therefore, it is important for teachers to convince their students that making mistakes is not bad, by contrast, they can learn from their mistakes. More importantly, teacher's harsh error correction or feedback need to be eliminated as this prevents students from engaging in speaking activities in the class.

Speaking in front of people is obviously one of the most common phobias that students encounter. The feeling of shyness, anxiety and low self-confidence makes their mind empty and they will forget what to say. As a result, most of the students fail to perform the speaking performance at their best. To sum up, the factors above should be taken into consideration when teaching speaking skills. For instance, English teachers can speak to the students privately or give them more opportunities to work in pairs or groups to gradually reduce their embarrassment, shyness, anxiety, lack of confidence during the English-speaking class.

It is noticeable that motivation is a key factor in making students' progress in speaking English. Consequently, instructors should create a comfortable, friendly environment and deliver interesting, updated topics for discussion, organize a variety of activities such as role-playing, interviewing, presenting, etc. to encourage all students to work attentively and eagerly during learning hours. In addition, teachers need to control classroom discussion effectively to ensure that student's participation is not dominated by a minority of participants, all students should get a chance to speak fairly.

Many students claim they have no idea to say due to the lack of socio-cultural knowledge. Therefore, teachers should introduce useful sources of material for students to read in order to widen their knowledge, so they will have more ideas to present when taking part in discussion in speaking class.

Besides, lecturers should pay more attention to teach learners oral communication strategy use in case they are unable to find the appropriate words, structures during their speaking and provide them useful idiomatic expressions or collocations so that they can manage oral communication successfully.

Finally, teachers should give more speaking activities so that students can discuss, present and practice speaking English as much as possible; and encourage students to communicate in English with teachers and friends, or join English speaking clubs, where they can share and talk about anything in English. 


\section{Conclusions}

The research findings indicate that BVU'S English major students face many speaking skills problems, namely linguistic problems and non-linguistic problems.

With regard to linguistic problems, the frequent items most students encounter are (1) think in their mother lounge first when they present topic, (2) lack vocabulary, (3) have poor pronunciation, (4) do not know how to use appropriate words in different contexts, (5) lack grammar knowledge and (6) have difficulties making completed sentences to express their opinion and (7) find it hard to remember vocabulary, especially words having more than one meaning.

In addition, there are two main kinds of non-linguistic problems the researcher has found in this study, which are psychologically and socially - related problems and lecturer's teaching methodology- related problems. The former reveals that students have difficulty speaking English because they are often (1) afraid of making mistakes in class, (2) shy and not confident to speak in front of the crowd, (3) anxious to communicate in English, especially with foreign teachers, (4) demotivated by better performance of other students in class and (5) they have difficulty finding chances to practice speaking skills outside the classroom. The latter consists of factors affecting students' interests and progress in speaking as follows: lecturers (1) do not give interesting topic for discussion, (2) use traditional teaching method and do not organize interesting class activities, (3) put less emphasis on idiomatic expressions or collocations to present ideas, (4) do not instruct students when they are unable to find the appropriate words, structures during their speaking and (5) deliver harsh error correction or feedback.

English lecturers, consequently, are expected to recognize speaking skills problems faced by students so that they can seek solutions to maximize the effectiveness of their speaking classes, which enhances students' speaking ability. It is also suggested that EFL learners should take every chance to practice speaking English because practice makes perfect performance.

\section{References}

Brown, H. D. (2001). Teaching by Principles: An Interactive Approach to Language Pedagogy. New York: Longman.

Byrne, D. (1984). Language learning in the classroom: Teaching oral English. Hong Kong: Longman.

Carter, R. \& Nunan, D. (2004). The Cambridge Guide to Teaching English to Speakers of Other Languages, Cambridge: CUP.

Chaney, A. L., and Burk, T. L. (1998). Teaching Oral Communication in Grades K-8. Boston: Allyn \& Bacon.

Harris, D. P. (1974). Testing English as a Second Language. New Delhi: Tata.

Lado, R. (1964). Language Teaching: A scientific Approach. New York: McGraw-Hill, Inc. 
Lazarton, A. (2001). Teaching oral skills. Boston, MA: Heinle \& Heinle.

Lindsay, C., \& Knight, P. (2006). Learning and teaching English: A course for teachers. Oxford: OUP.

Nunan, D. (1991). LanguageTeaching Methodology. A Textbook for Teachers. New York: Prentice Hall International, Ltd.

Penny, Ur. (1996). A Course in Language Teaching Practice and Theory. Cambridge: CUP. Richards, C. (2006) Communicative language teaching today. New York: CUP.

Shumin, K. (1997). Developing adult EFL students' speaking abilities. Cambridge: CUP. Thornbury, S. (2005). How to teach speaking. Essex: Pearson Education. 
Huynh Thi Anh Tram

PROBLEMS OF LEARNING SPEAKING SKILLS ENCOUNTERED

BY ENGLISH MAJOR STUDENTS AT BA RIA-VUNG TAU UNIVERSITY, VIETNAM

Creative Commons licensing terms

Authors will retain the copyright of their published articles agreeing that a Creative Commons Attribution 4.0 International License (CC BY 4.0) terms will be applied to their work. Under the terms of this license, no permission is required from the author(s) or publisher for members of the community to copy, distribute, transmit or adapt the article content, providing a proper, prominent and unambiguous attribution to the authors in a manner that makes clear that the materials are being reused under permission of a Creative Commons License. Views, opinions, and conclusions expressed in this research article are views, opinions and conclusions of the author(s). Open Access Publishing Group and European Journal of English Language Teaching shall not be responsible or answerable for any loss, damage or liability caused in relation to/arising out of conflict of interests, copyright violations and inappropriate or inaccurate use of any kind content related or integrated on the research work. All the published works are meeting the Open Access Publishing requirements and can be freely accessed, shared, modified, distributed and used in educational, commercial and non-commercial purposes under a Creative Commons Attribution 4.0 International License (CC BY 4.0). 